\title{
Florida 4-H Tailgating Contest Handbook
}
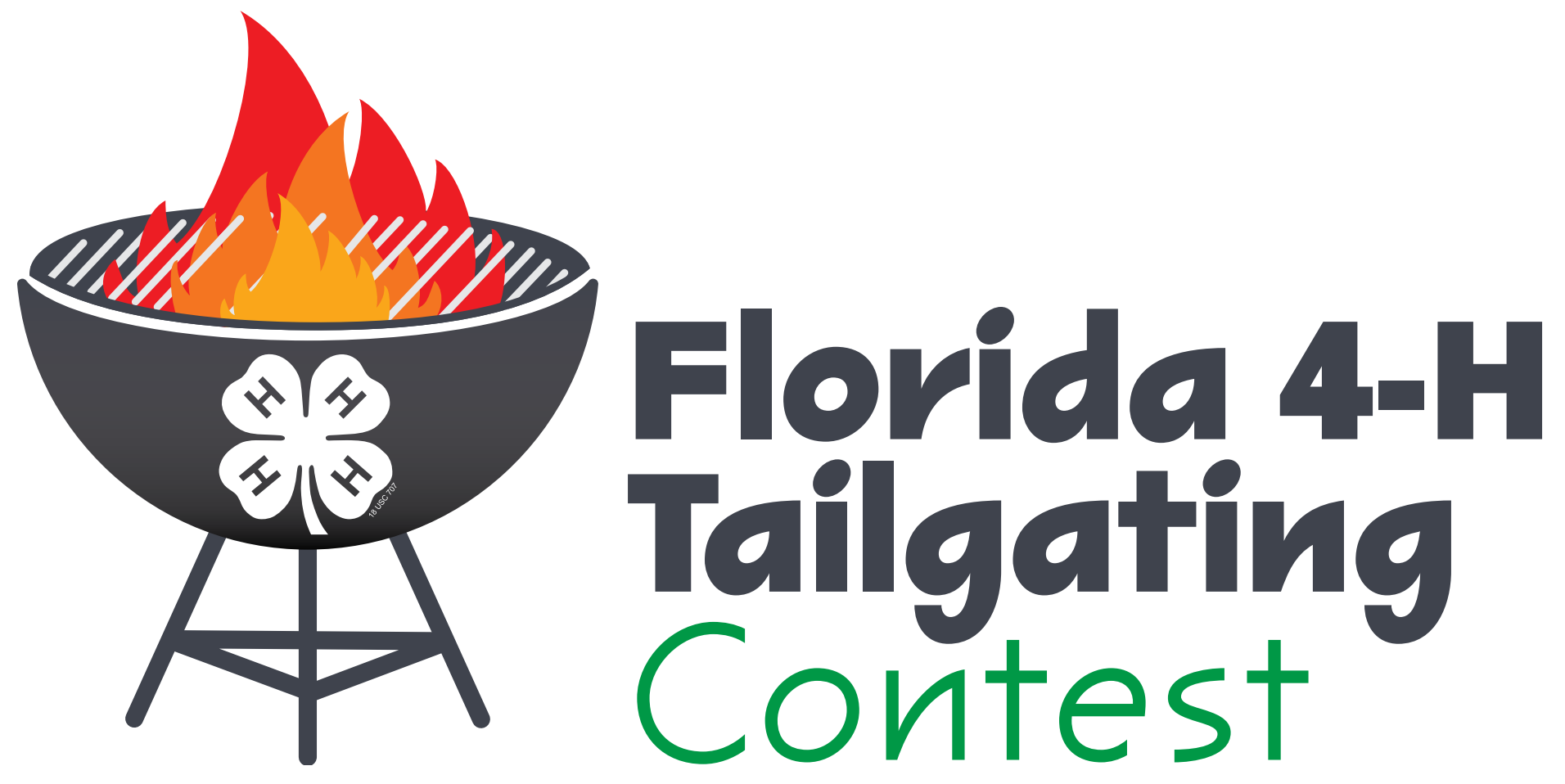

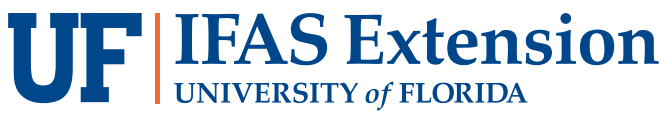

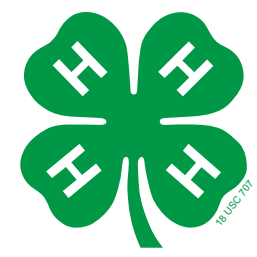




\section{Contest Purpose}

The purpose of this contest is to promote the use of animal protein in the diet by teaching the art and science of safely preparing beef, pork, chicken, and shrimp in an outdoor setting. Investment in this activity will provide 4-H youth with life skills, including decision-making, healthy lifestyle choices, and communication.

\section{Contest Eligibility}

All bona fide Florida 4-H members between 11 and 18 years of age prior to September 1 of the current 4-H year are eligible. Participants who have previously placed 1st or 2nd for a given protein at the state contest cannot participate in that same protein. All participants are required to prepare their recipe in the presence of a parent or guardian prior to the contest.

A minimum of four contestants are required to compete in a protein for prizes to be awarded, but if three or fewer compete, all will be allowed to go forward to the state contest.

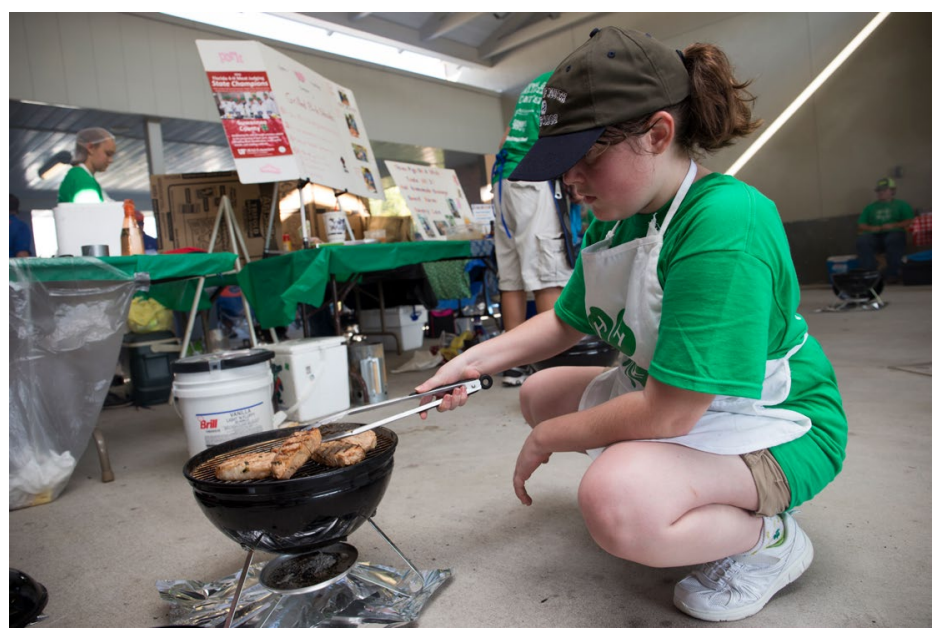

The state winner or highest placing senior (14 years of age by January 1 of the current year) for chicken will be eligible to participate in the National Poultry Cookery Contest in Louisville, KY. At the National Contest, the Florida representative must prepare an unmarinated, entire, and intact half chicken or turkey breast for judging. However, this is no longer a requirement for the Florida 4-H Tailgating Contest.

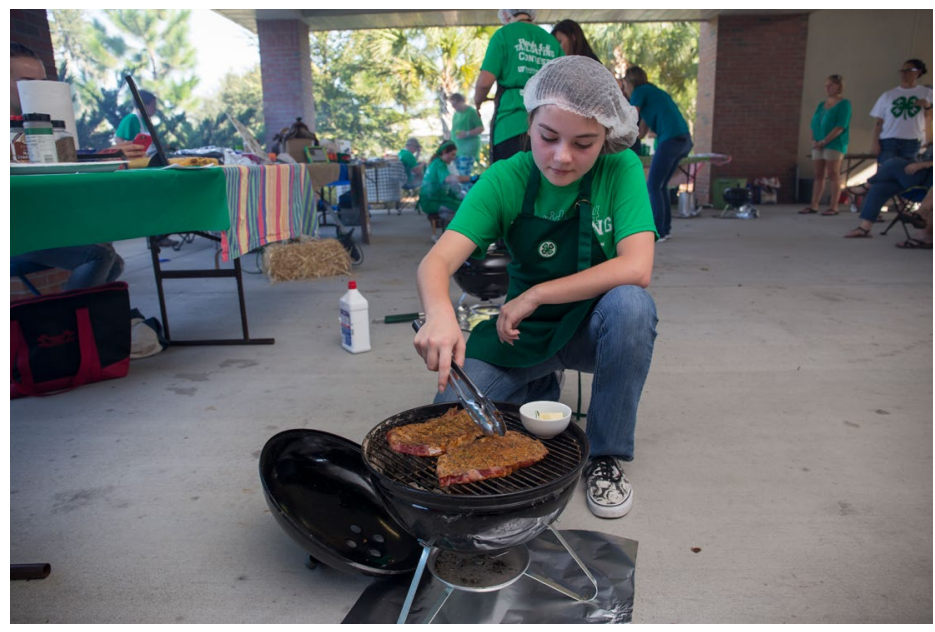

Tablecloths are no longer allowed at the Florida 4-H Tailgating Contest. 


\section{Protein Categories}

Each contestant must provide enough fresh, uncooked, animal protein for two, 6-8 oz. cooked portions to serve the judges for palatability evaluations. The protein categories are as follows:

- Beef

- Pork

- Chicken

- Shrimp

» The only eligible seafood item is headless, deveined, fresh shrimp.
Beef, pork, chicken, and shrimp may be marinated prior to the contest. Sauces and marinades may be commercial or personal recipes.

\section{Contest Overview}

\section{One hour prior to 14 " Weber grills being started:} Contestants must have their uncooked proteins and cooler temperatures checked at registration. Each contestant will fill out their contestant card, and a carbon copy will be taped to the plate/ container that they turn in for palatability judging. Uncooked proteins must be covered at all times and maintained at $\leq 40^{\circ} \mathrm{F}$. Temperature abuse is a food safety issue and will result in point deductions. Contestants with temperature-abused proteins $\left(\geq 50^{\circ} \mathrm{F}\right.$ ) will not be allowed to compete. Personal clothing should follow the $4-\mathrm{H}$ dress code, be clean and neat, and not present a safety concern (no loose-fitting clothing or open-toed shoes). Long hair should be secured for food and fire safety.

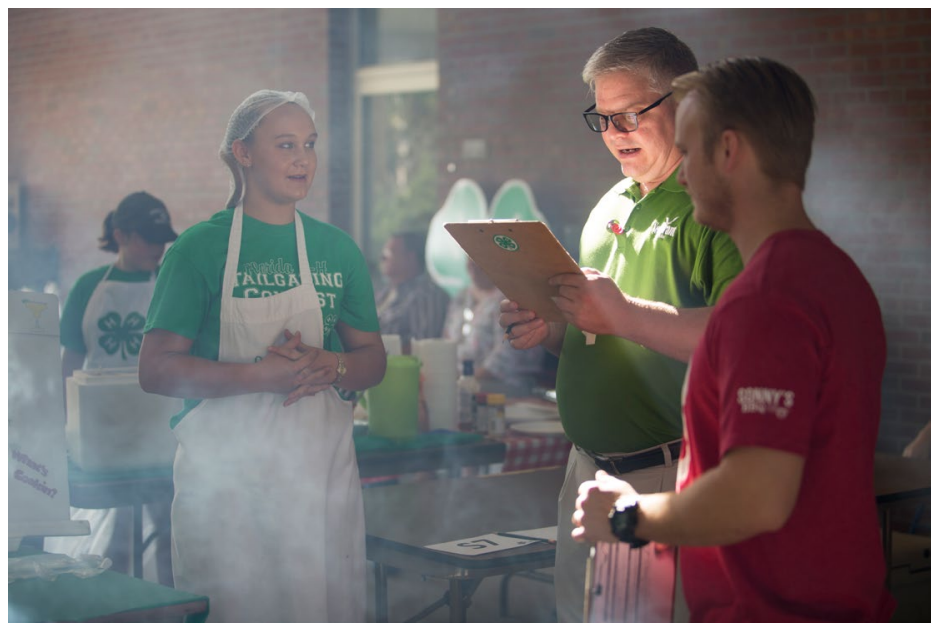

Thirty minutes prior to grills being started: Contestants will prepare their tables, fires, and proteins without assistance from other $4-\mathrm{H}$ members or adults. Due to fire safety concerns, contestants will not be allowed to use tablecloths or have loose-leaf paper on display. Other fire safety concerns can be addressed by the contest coordinator. Contestants can use a laptop/iPad/ poster \& easel to complement their tabletop display to describe their recipe.

Fire and food safety will be observed by two (if possible) judges per protein. Contestants may not light their grills until the designated start time. Contestants must provide grilling supplies. All grills must be placed on the ground for safety reasons.

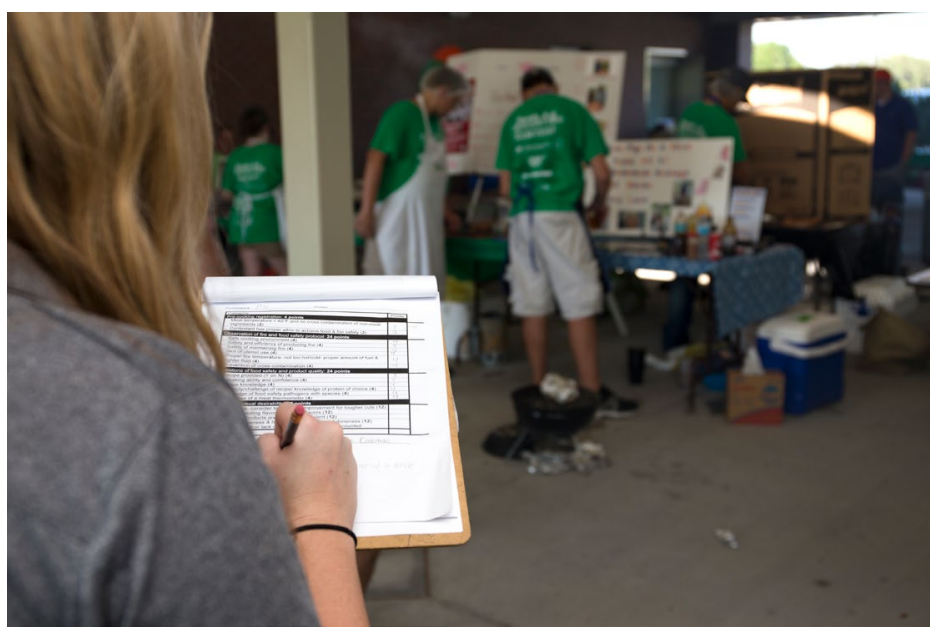

Tablecloths are no longer allowed at the Florida 4-H Tailgating Contest. 


\section{Judging}

The fire and food safety judges will ask participants questions about their recipe and safety knowledge after all contestants have been observed. Contestants should expect questions relative to their table display, proper use of a meat thermometer, and the tailgate curriculum series linked below. Contest participants must have a fire and food safety judge assess proper cooking temperature/degree of doneness before submission. A team of three judges (if possible) will evaluate cooked submissions.

Entries will be submitted at specified time windows after grills have started:
- Shrimp: 45 min-1 hour 15 min

- Pork: 1 hour-1 hour 30 min

- Beef: 1 hour 15 min-1 hour 45 min

- Chicken: 1 hour 30 min-2 hours

Entries submitted outside of those windows will be deducted 10 points.

No additional items (drink, garnish, vegetables, etc.) should be submitted. Judges will be instructed to independently score all components of the entries turned in for palatability assessment (i.e., skin, dark, and white meat). If present, bacon will be removed prior to consuming the product.

\section{Contest Curriculum}

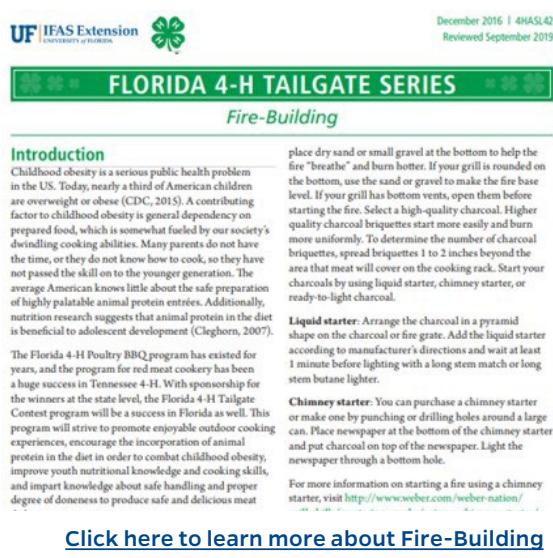

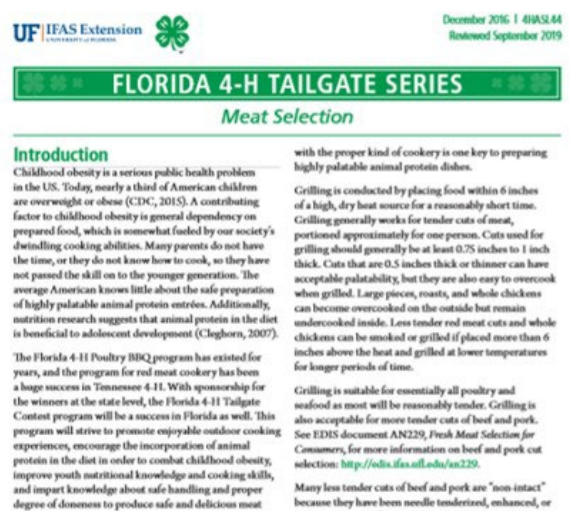

Click here to learn more about Meat Selection

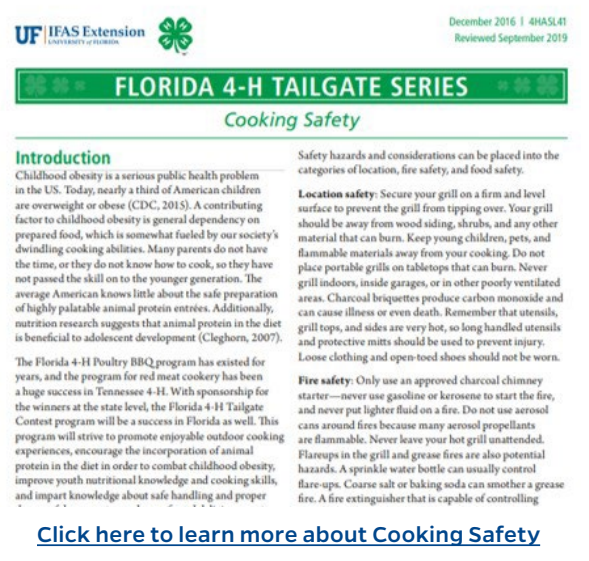

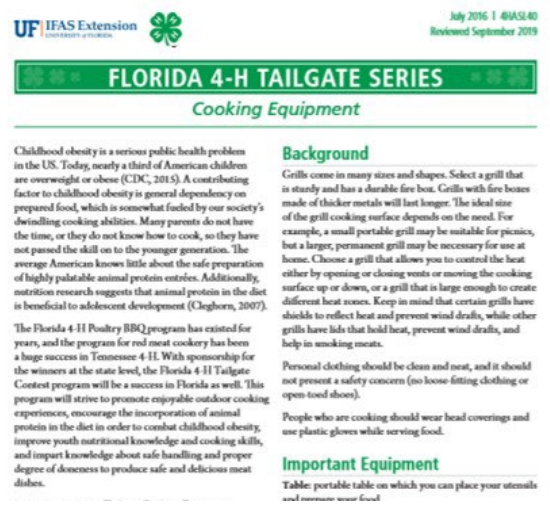

Click here to learn more about Cooking Equipment

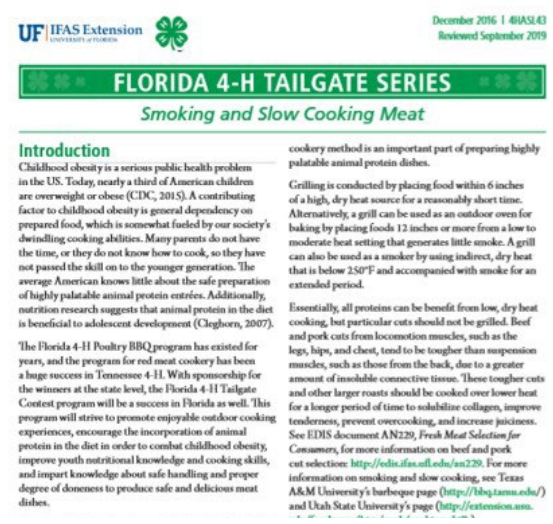

Click here to learn more about Smoking and Slow Cooking Meat 


\section{Scorecard}

Contestant \#

Protein

Category

Points

Pre-cooking registration: 4 points

Meat temperature $<40^{\circ} \mathrm{F}$ and no cross contamination of non-meat ingredients (2)

Contestant has proper attire to achieve food \& fire safety (2)

Observation of fire and food safety protocol: 24 points

Safe cooking environment (4)

Safety and efficiency of producing fire (4)

Safety of maintaining fire (4)

Skill of utensil use (4)

Proper fire temperature- not too hot/cold- proper amount of fuel \&

lighter fluid (4)

Prevention of cross-contamination (4)

Questions of food safety and product quality: 24 points

Recipe provided (Y on N) (4)

Speaking ability and confidence (4)

Recipe knowledge (4)

Creativity/challenge of recipe/ knowledge of protein of choice (4)

Knowledge of food safety pathogens with species (4)

Proper use of a meat thermometer (4)

Eating and visual desirability: 48 points

Tenderness- consider tenderness improvement for tougher cuts (12)

Flavor: Appealing flavor with no off flavors (12)

Juiciness: Products are juicy and succulent (12)

Total attractiveness \& hitting targeted degree of doneness (12)

${ }^{* *}$ Dark or light or lack of uniform color ash are discounted

Total: 100 points

Judge

Comments: 


\section{Awards}

\section{District Contest}

For each protein category:

- 1st Place: $\$ 400$

- 2nd Place: $\$ 250$

- 3rd Place: $\$ 100$

- 4th Place: \$50

\section{State Contest}

For each protein category:

- 1st Place: $\$ 1,500$

- 2nd Place: $\$ 1,000$

College Scholarships to a postsecondary institution of your choice.

The top 2 individuals from each category are invited to compete at the State Competition.

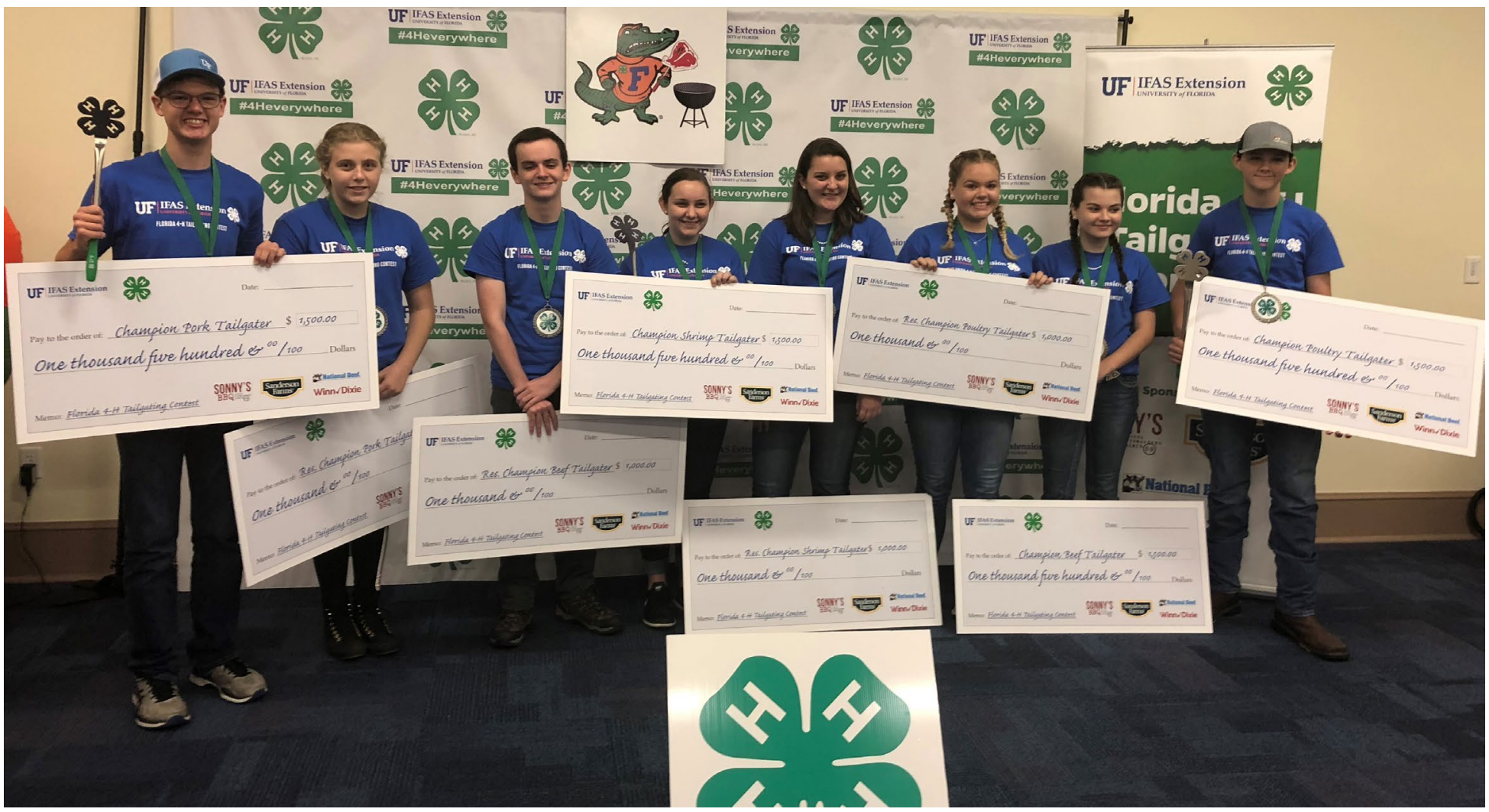

\section{Scholarship Fund Disbursement}

Payment of scholarship funds will be made directly to the accredited college/university, technical/trade school, or college education/529 fund on behalf of the recipient. To receive your scholarship disbursement, winners must submit the following to the State 4-H Headquarters: two thank-you notes written to the donors of the awarded scholarship(s); verification of the student's postsecondary enrollment, which could be a letter from the institution, class schedule, or receipt from the institution with the student's name printed; name and address of the financial aid office of the student attends or will attend; education/529 fund information; 529 account number or Institution Student ID.

In the event of special education needs, payment of scholarship awards can be directed to the recipient upon prior approval of the State Extension Specialist. Under these conditions, an IRS Form 1099-MISC will be filed with the Internal Revenue Service and the recipient for the calendar year in which it is received. 


\section{Recipe Development}

Visit these links to learn more about recipe

development:

UF $\mid$ IFAS Extension

FSHN13-03

\section{Shopping for Health: Herbs and Spices ${ }^{1}$}

Jenna A. Norris and Wendy Dahl²

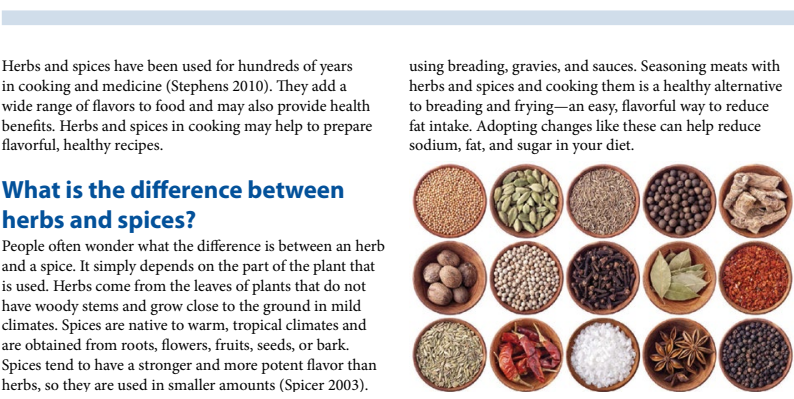

Click here to learn about UF/IFAS' Shopping for Health: Herbs and Spices
UF/IFASExtension $\frac{A B}{6}$

\begin{tabular}{|c|c|}
\hline FLORIDA 4-H & ILGATE SERIES \\
\hline \multicolumn{2}{|c|}{ Smoking and Slow Cooking Meat } \\
\hline Introduction & cookery method is an important purt of prepuring bighly \\
\hline \multirow{9}{*}{ 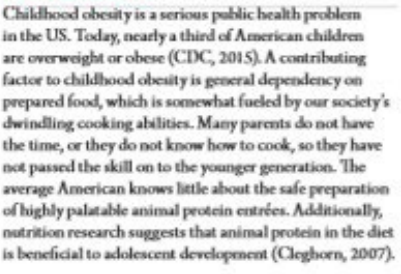 } & \\
\hline & Grilling is conducted by placing food within 6 inches \\
\hline & of \\
\hline & 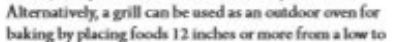 \\
\hline & grates little smoke. A grill \\
\hline & can alwo be uned as a umoker by waing indireat, dry he \\
\hline & $\begin{array}{l}\text { that is below } 2 \text { So"F and accompanied with sencke for } \\
\text { extended peried. }\end{array}$ \\
\hline & \\
\hline & $\begin{array}{l}\text { Eissentially, all proteins can be benefin frow low, dry beat } \\
\text { cooding, lat particular conts showld soct be grilled. Beed }\end{array}$ \\
\hline & \\
\hline & masdes, sach as those from the back, doe to a greater \\
\hline & 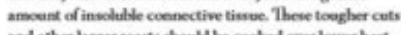 \\
\hline
\end{tabular}

Click here to learn about UF/IFAS' Smoking and Slow Cooking Meat

Tips for Making a BBQ Rub

$\bullet$ Updated August 06, 2020

Amanda Blair

\section{About BBQ Rubs}

A rub is simply a blend of herbs, peppers, spices or seasonings that are blended to add flavor by coating the surface of meat. of all dry ingredients or they can include oils, crushed garlic or other liquids that cause the rub to take the form of a paste.

Rubs can be applied just before cooking or several hours ahead of time, this is a personal choice. Rubs do not need to be appli but can be applied to the surface of meat just before grilling, roasting or barbequing. For convenience rubs can be applied se before cooking, however the meat should be covered and refrigerated to maintain food safety. Many flavors will become mor longer the rub stays on the meat.

Click here to learn about SDSU Extension's Tips for Making a BBO Rub

Pinchin' Pennies in the Kitchen

\section{Do It Yourself Spice Mixes}

Making your own spice blends is a win-win idea that gives your food a pop of flavor while reducing sodium.

Herbs come from the leaves of shrubs. Spices come from other parts of plants.

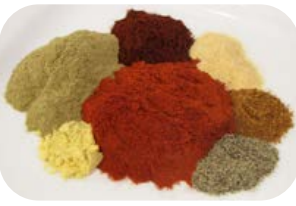

Did you know? For example, 1 teaspoon of garlic salt adds abou
970 milligrams (mg) of sodium to a recipe, while teaspoon of garlic powder adds only $2 \mathrm{mg}$ of sodium.

Make it your own

Make changes according to what you and your family tavorites. Experiment with different amounts and varieties

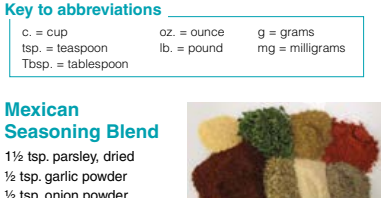

Click here to learn about NDSU Extension's Do it Yourself Spice Mixes

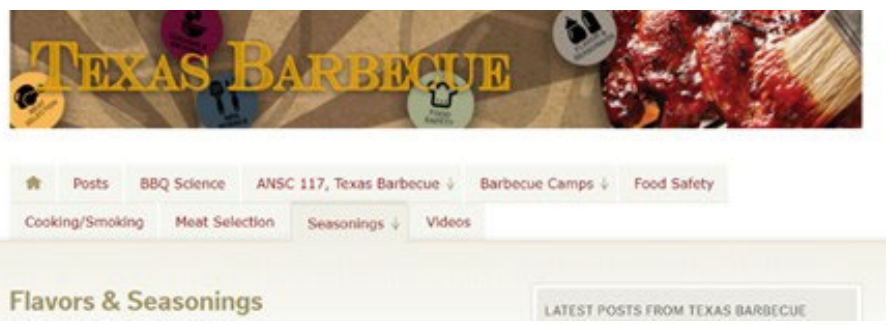

Click here to learn about Texas A\&M's Flavors \& Seasonings 


\section{Competition Day Checklist}

\section{The contest will provide:}

- Grills

- Charcoal

- Lighter fluid

- Half of an $8 \mathrm{ft}$ table

- Paper plates to turn in protein

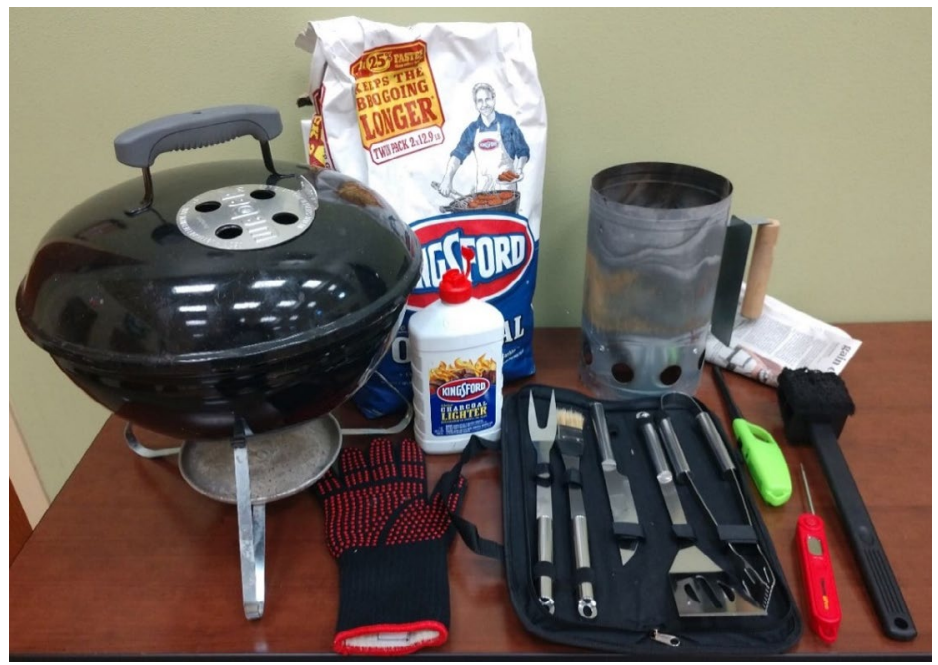

\section{Contestants will need to provide:}

- Meat (must be under $40^{\circ} \mathrm{F}$ at check-in)

- Spices, seasonings, marinades, and/or rubs

- Grilling utensils

- Meat thermometer

- Striker/lighter

- Recipe table display

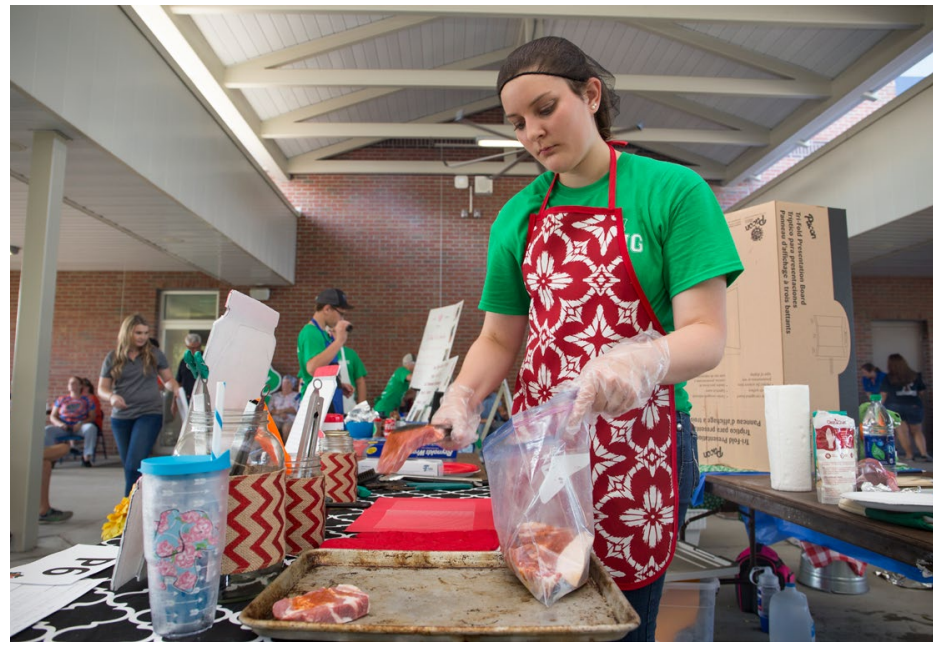

Tablecloths are no longer allowed at the Florida 4-H Tailgating Contest.

\section{Contestants are recommended to bring:}

- Cooler

- Chimney and newspaper

- Grill brush

- Hot glove

- Pliers

- Recipe cards

- Fire-safe table decorations

- Apron

- Gloves

- Hairnet/hat

- Pen/pencil

- Sanitizing wipes
- Timer

- Aluminum foil

- Aluminum baking trays

- Tongs (4-6)

- Basting brush

- Spatula

- Mixing bowls

- Measuring spoons

- Measuring cup

- Cutting board(s)

- Other grilling items as needed 


\section{Food Safety}

\section{Clean}

- Wash your hands and surfaces often.

- Wash your cutting boards, dishes, utensils, and countertops with hot soapy water after each use.

- Consider using paper towels to clean kitchen surfaces instead of cloth towels.

\section{Cook}

- Cook the food to the correct temperature.

- Always use a food thermometer to measure the internal temperature of cooked foods.

- Never assume the food is cooked based on color.

- The food is done when it reaches the safe minimum internal temperature.

\section{Separate}

- Separate raw meats from other foods.

- Keep raw meat, poultry, seafood, eggs, and juices away from other foods.

- Always remember to:

» Separate raw meat, poultry, seafood, and eggs from other food in the shopping cart, grocery bags, and refrigerator.

» Never place cooked food on a plate that previously held raw meat.

» Do not reuse marinades.

\section{Chill}

- Refrigerate or freeze meat within 2 hours of cooking or purchasing.

- Never thaw food at room temperature.

- Always marinate in the refrigerator.

- Use or discard refrigerated food on a regular basis.

- Microwave: Place meat in a microwave-safe bowl. Microwave for two minutes, then let stand for one. Repeat as needed. Cook immediately.

\section{How to properly thaw meats:}

- Refrigerator: place your meat in a container that has a lid, and place it in the refrigerator for 1-2 days to thaw.

- Cold water: Place meat in a leak-proof bag and submerge in cold water. Change water every 30 minutes. Cook immediately.

\section{More Resources}

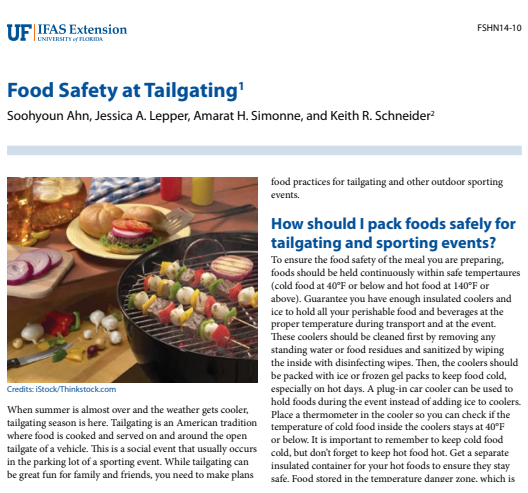

Click here to learn about Food Safety at Tailgating.

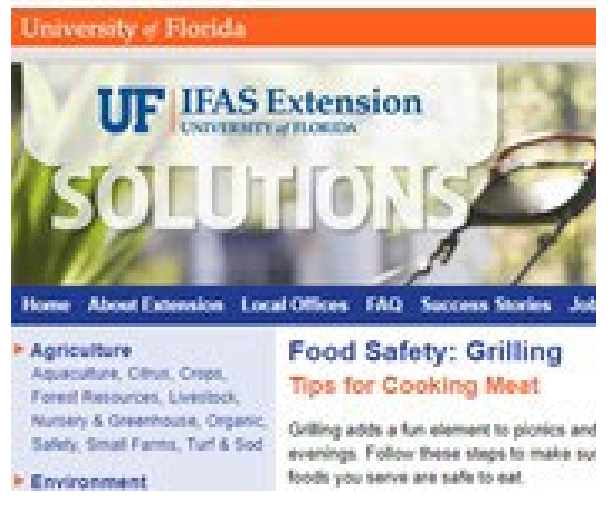

Click here to learn about UF/IFAS' Food Safety: Grilling
CDCG Centers for Disecese Contiol and Priverntion

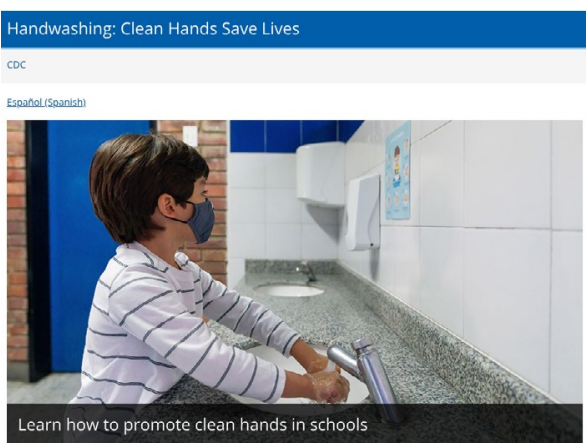

Click here to learn about CDC's Hand washing. 


\section{Temperature}

\section{How to calibrate a dial thermometer:}

1. Fill a glass with ice and water.

2. Put the thermometer in the water and let it sit for one minute.

3. The thermometer should read $32^{\circ} \mathrm{F}$. If it does not read $32^{\circ} \mathrm{F}$, adjust the gauge by twisting the nut on the back.

\section{How to check internal temperature:}

Place the thermometer in the thickest part of the meat. Ensure that it is not touching bone, fat, or gristle. Be sure to clean your thermometer after each use.

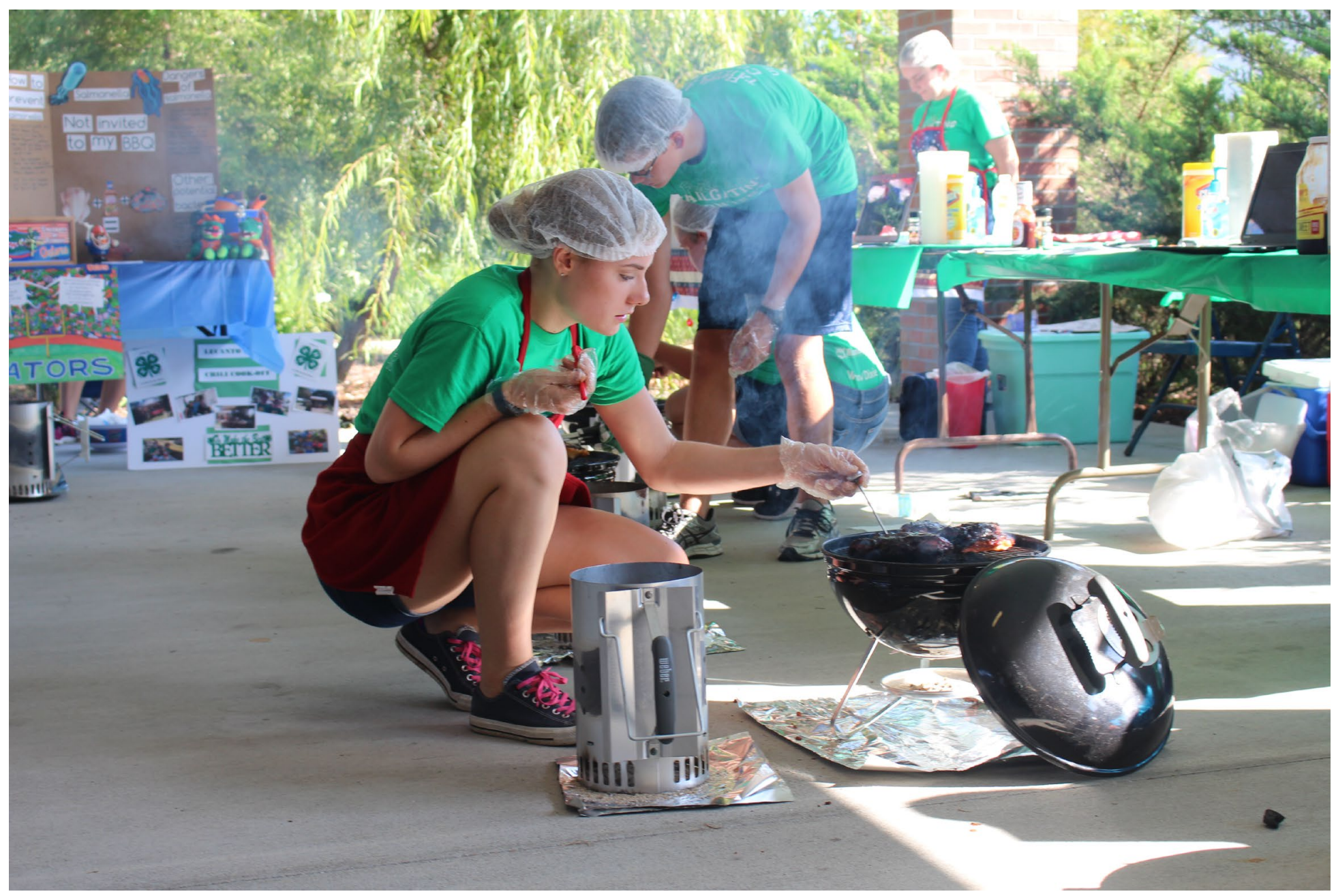

Tablecloths are no longer allowed at the Florida 4-H Tailgating Contest.

\section{Recommended Internal Temperatures:}

- Beef: $145^{\circ} \mathrm{F}$

- Shrimp: $145^{\circ} \mathrm{F}$

- Pork: $145^{\circ} \mathrm{F}$
- Ground Meat: $160^{\circ} \mathrm{F}$

- Chicken: $165^{\circ} \mathrm{F}$ 


\section{Fire Safety}

- Never put lighter fluid on a lit fire.

- Never leave your hot grill unattended.

- Coarse salt or baking soda can smother a grease fire.

- Make sure coals are cold before disposing of them.

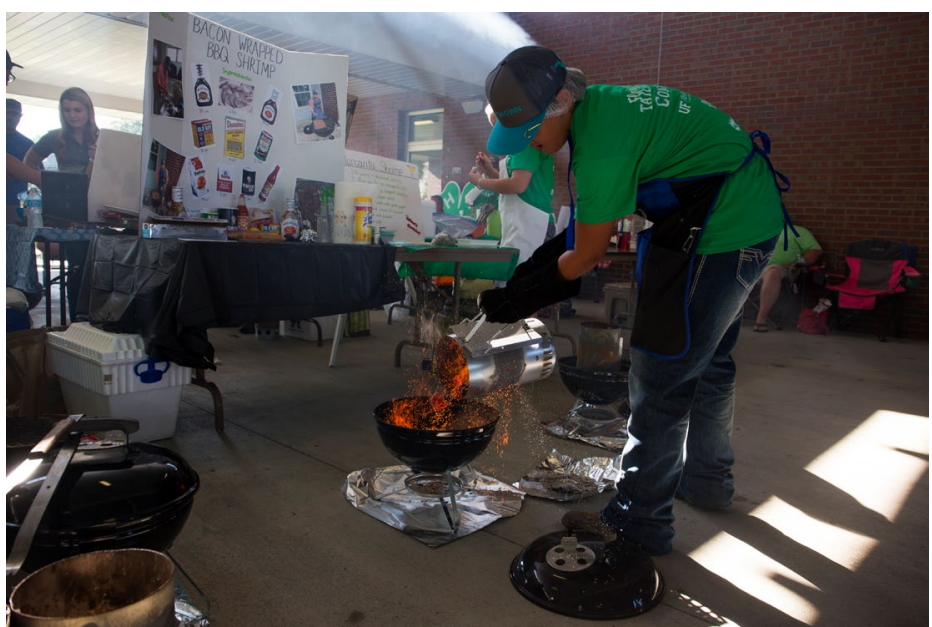

Tablecloths are no longer allowed at the Florida 4-H Tailgating Contest.
- Keep young children, pets, and flammable materials away from your grill.

- Loose clothing and open-toed shoes should not be worn when grilling.

- Long hair should be secured for food and fire safety.

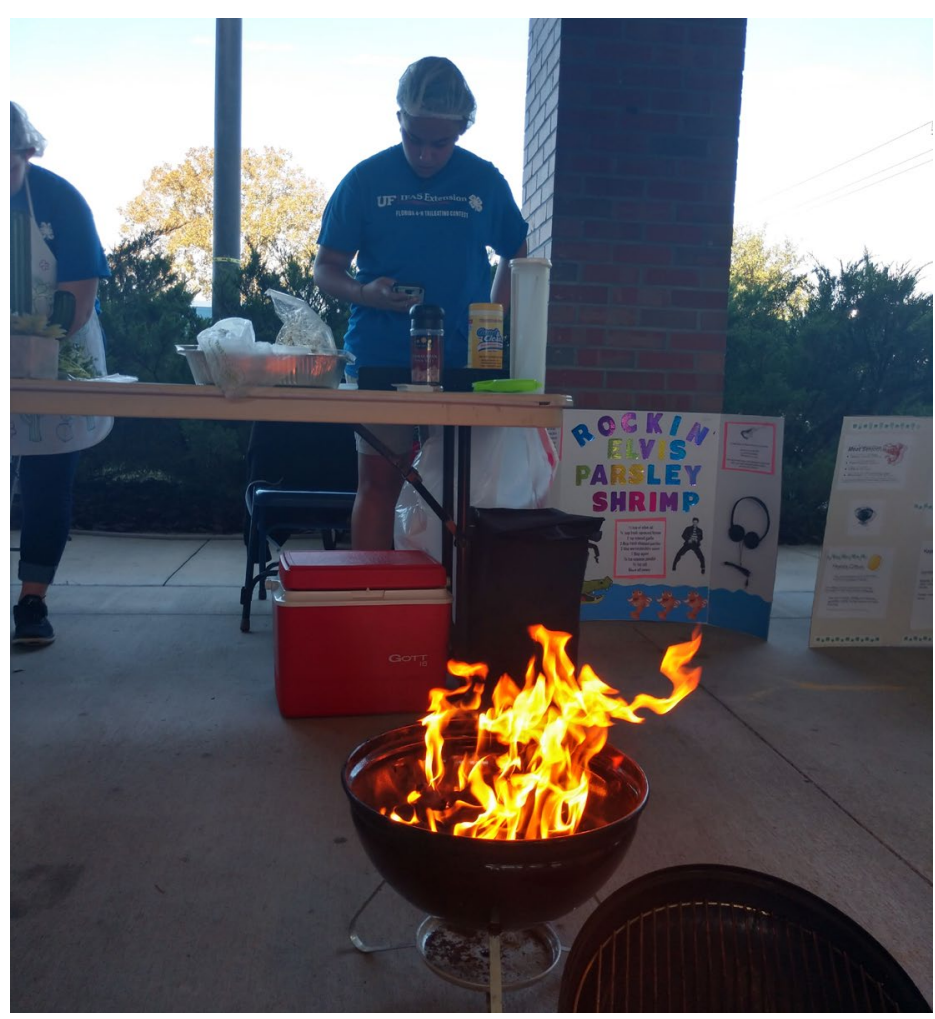

\section{More Resources}

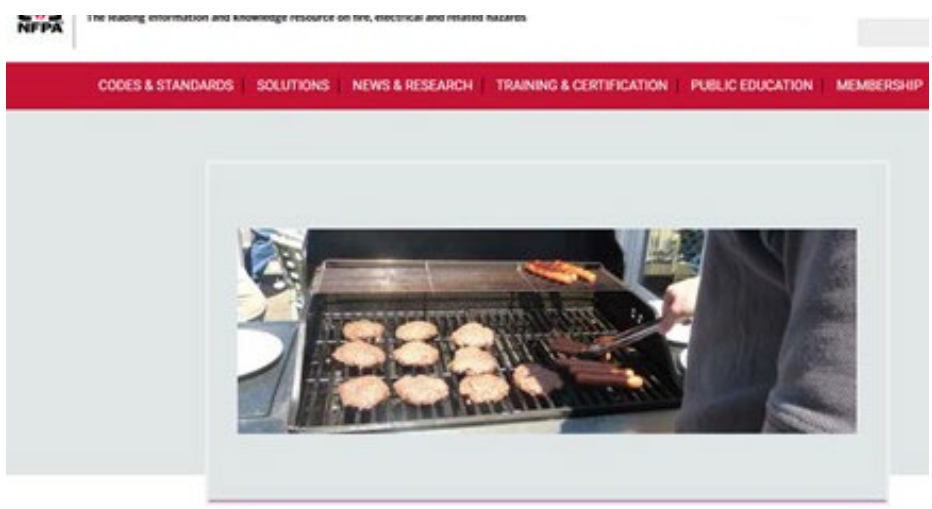

SNETT SOUACE - JUEE 28, 2013

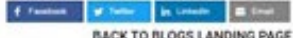

4 grilling fire safety resources to get your summer cooking events off on the right foot

Click here to learn about National Fire Protection Association's Grill Safety.
UF IFASExtension
December 2016 | 4HASL41 Reviewed Septembet 2019

\section{EK $:$ FLORIDA 4-H TAILGATE SERIES}

Cooking Safety

\section{Introduction}

Childhood obesity is a serious public health problere in the US. Today, nearly a thind of American children are overweight or obese (CDC, 2015). A contributing factor to childhood obesity is general dependency on prepared food, which is somewhat foeled by our society' dwindling cooking abdinies. Many parents do not have the time, or they do not know how to cook, so they have not passed the skill on to the younger generation. The awrage American knows lit le about the cufe preparation of highty palutuble animal pereein eatotes, Additionally.

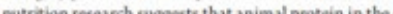

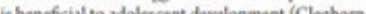

The Florida 4-H Poultry BBQ program has existed for rears, and the program for med meat cockety hus b. a huge successin Tennessee 4-H. Wish spon

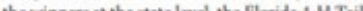

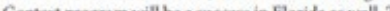

Safety hazards and considerations can be placed into the categories of location, fire safety, and food safety.

Locatioa safety: Secure your grill on a firm and lewel surtace to prevent the gril from tipping owr. Your grill should be wawy froen wood siding, shrubs, and any other material that can burn. Keep young children, pets, and

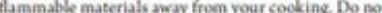

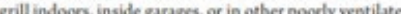
a, .

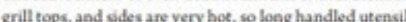
grillops, and dades are very hot, ro long handed utenals Clothing and open-toed shoes should not be wor.

Fire safety: Only use an approwed charcoul chimney starter-never use gasoline of kerosene to stant the fire,
and newer put lighter fluid on a fire. Do not use aerosol

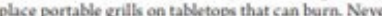
and protective miets inoula be uned to prewent injury. starter-never ase gaveline of kerosene to start the fire, Click here to learn more about Cooking Safety 


\section{Fire Building}

There are multiple ways to light your coals. You can use lighter fluid, a chimney starter, or ready-to-light charcoal. Never use gasoline or kerosene to start a fire, and never add lighter fluid to hot coals. Give all lighter fluids time to completely burn off to avoid an "off taste" in what you are grilling. Adjust the airflow of the grill by adjusting the vents at the top and the bottom. Closing the vents cuts off the air and suffocates the fire.

\section{Lighter Fluid:}

Step 1: Arrange the coals in a pyramid in your grill.

Step 2: Add lighter fluid to coals.

Step 3: Wait at least one minute before lighting coals with a long-stem match or a long-stem butane lighter.

\section{Chimney Starter:}

Step 1: Place newspaper in the bottom of the chimney.

Step 2: Pour your coals in the chimney.

Step 3: Light the newspaper through the bottom holes of the chimney.

Step 4: Dump the charcoals into the grill when they become slightly gray from ash.

\section{Ready-to-Light Charcoal:}

Step 1: Arrange the coals in a pyramid in your grill.

Step 2: Light the coals with a longstem match or a longstem butane lighter.

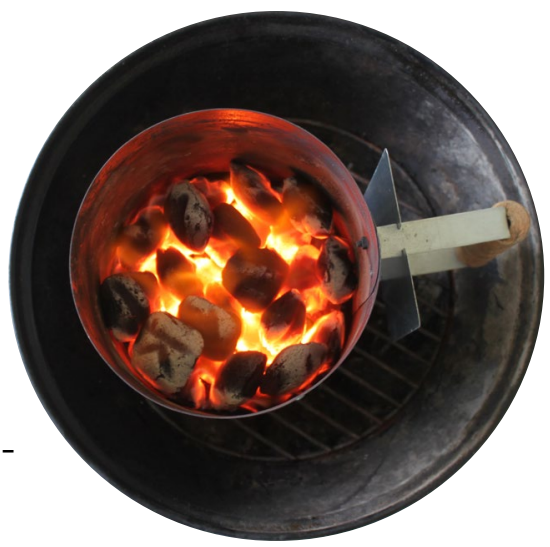

\section{More Resources}

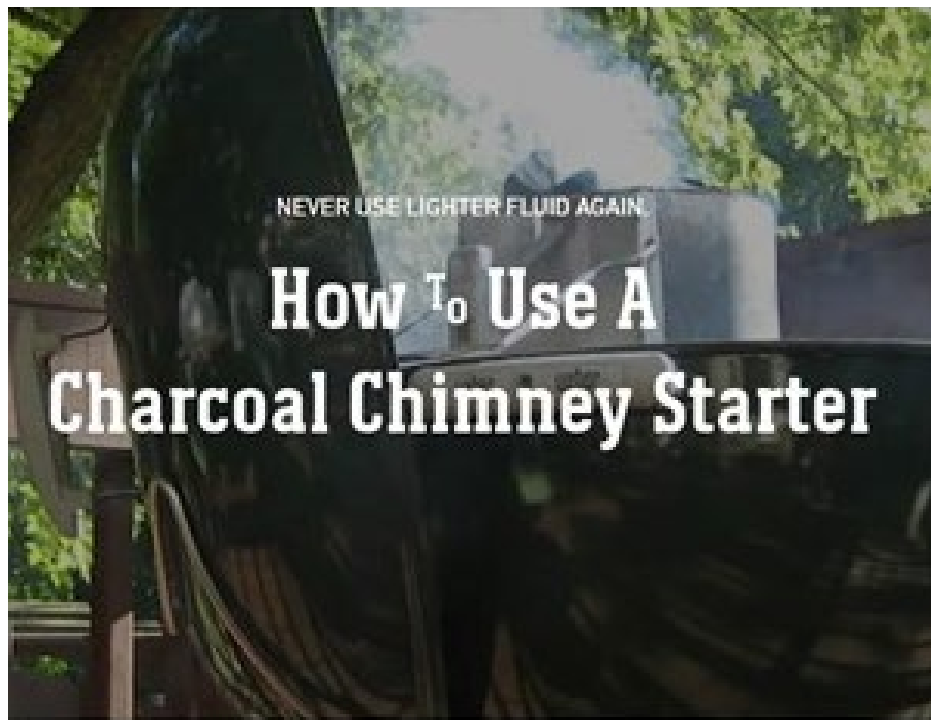

Click here to learn about Weber's Chimney Starter.

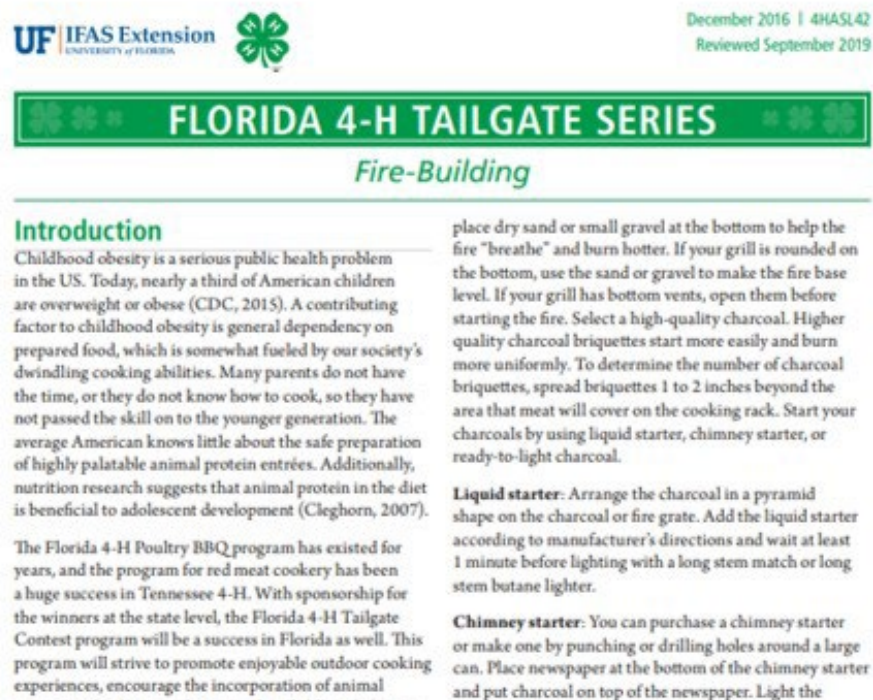

Click here to learn more about Fire-Building 


\section{Meat Selection}

Click here to learn about meat selection.

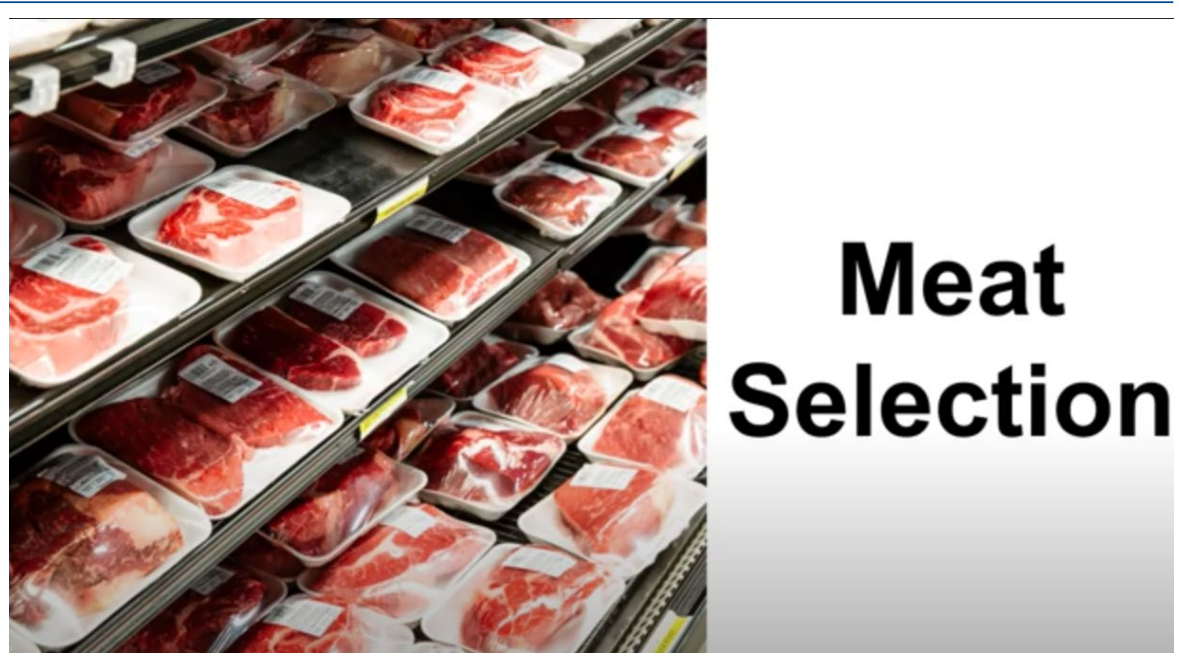

\section{More Resources}

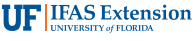

Fresh Meat Selection for Consumers ${ }^{1}$

Chad Carr, Ed Jennings, and Larry Eubanks²

A solid working knowledge of fresh meat terminology
will help consumers select meat cuts which will perform will help consumers se

The three red meat species generally offered in US retail markets are beef, pork, and lamb. The processing plant will slaughter the live animal to generate a carcass, with beef and pork carcasses being divided into sides. Carcasses are chilled to ensure food safety and quality. Almost all carcasses from meat animals are cut into wholesale cuts while at the initial slaughter plant (Figure 1). Most food service distributors and some retailers have the ability to further cut primal and subprimals into retail cuts. Large

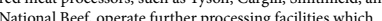
National Beef, operate further processing facilities which This minimizes skilled-labor costs for hore retalers such as Wal-Mart and Target.

The biological role of the muscles that comprise these cuts makes a huge influence on the ultimate eating quality, or palatability, of the products. Muscles attached to the for and/or hind limb are muscles of locomotion and these cut tend to have more connective tissue and be more inconsistent in cooked product tenderness than cuts from muscles of posture, though exceptions between and within species

Click here to learn about UF/IFAS Extension's Meat Selection.

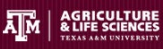

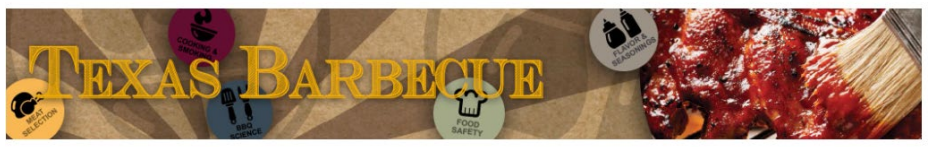

- Posts BBQ Science ANSC 117, Texas Barbecue $\downarrow$ Barbecue Camps $\downarrow \quad$ Food Safety

Cooking/Smoking Meat Selection Seasonings $\downarrow$ Videos

Meat Selection

LATEST POSTS FROM TEXAS BARBECUE

Click here to learn about Texas A\&M's Meat Selection

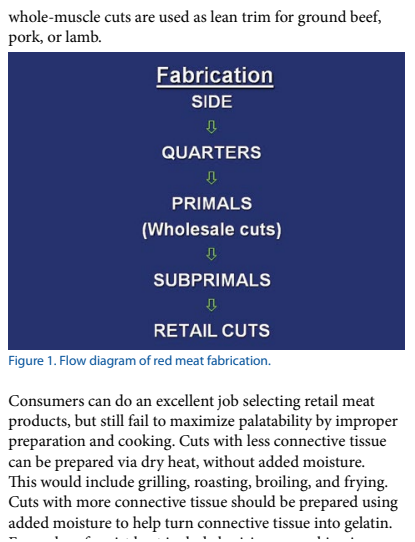

UF IFASExtension 8

Deomber 2016 I auses

Revioned Septenter 2019

\section{EF $\approx$ FLORIDA 4-H TAILGATE SERIES $\triangle E B$ Meat Selection}

Introduction

Challbood obenily is a rerious pullic health problem

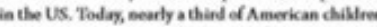
are overwingt of obvis (CDC, 2015). A contrithuting Gater to chilhood ebenity is gmeral dependency oe pepared food, which is wenewhat focled by our nociety"

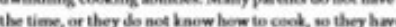

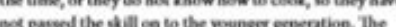

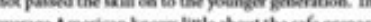

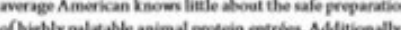

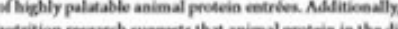
matritioe reserarch sungests that animal poutein in the diet is beneficial to adolescent development (Cleghorn, 2007) The Floriala 1 - II Poultry BBQ program has existed for years, and the pongram far red meat oekery las been a hage neccess is Tennense 4 11. Wiah ponsenkip for the minners at the state leved, the Fhenth st II Talkate Coetest program will te a soccess is Florida as well. This

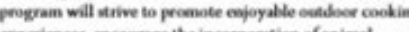
experiences, moeerake the incorportiben of animal protein in the dist in onder to combut chillhood oberity

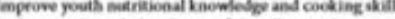
and impart knowledge aboet rafe handling and proper degpee of doneness to produce sfe and deticives mest Iwindling cooking abilities. Many parents bo not bave

\begin{abstract}
with the proper kind of cookery is one keg to propuring Mydly paladisto animal peotein didher.

Grilling is coenducted by placieg foed wathin 6 incher of a high, dry beat mource far a reasces ably bert time. Grilling smerally wouks for tender cats of mex. portiesed sproximately for one person. Cats used for

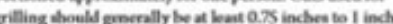
thick. Cuts thas are 0.5 inches thikk oe thinner can hare sccoptatle palatablity, bat they are aloo eary te overceed

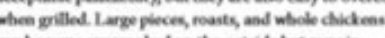
an become enercooked en the out tible but remain endercooked inside. Less tendar red meot cuts and abok chichens can be moked of grilled if placed more than 6 inches above the best and grilied at lower temperatures Gur hager periodh of time.

Crilling is suatatile bar exontially all poulary and ceafood as most mill bo reasoeably tedede. Grillieg is

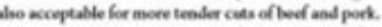
See EDIS documsent AN229, Thesh Moat Selection fur Conumen, for more information as bed mol port cut

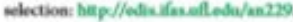

Many less tender cuts of beed and pork are "non intad" because they have been needle temderined, enhanced, of
\end{abstract}

\section{Click here to learn more about Meat Selection}

Purchasing meat

Meat plays a starring role in most menus. It is a valuable source of protein and minerals such as iron. Usually meat is the most expensive item
in the food budget, so it is important to shop wisely, considering both quality and quantity, and to properly store and prepare all types and cuts of
meat.

Prime, Choice, and Select grades contain the same nutrents, but Prime cuts of meat usually have more marbing and are more USDA tender, they cost more, too. Marbling refers to the focks What's the cost? thandwich spreads, salads, soups, casseroles, stir-fry combinations, and other dishes where SELECT complementary ingredients act as extenders.

Use the downloadable beef and pork charts below to help select the appropriate cooking methods for the cut of meat purchased. I
you have a slow cooker, microwave oven, or other special cooking equipment, learn to use them by following the manufactuere's instructions

For a printer-friendly version of the Retail Cuts of Beef chart, click on the icon to download. 国 Note: Must have Acrobat Reader.

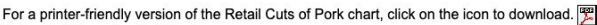
Note: Must have Acrobat Reader.

\begin{tabular}{|c|c|}
\hline \multicolumn{2}{|r|}{ Meat buying guide } \\
\hline & Purchasing fresh meats \\
\hline & $\begin{array}{l}\text { Beef should be red with fat content creamy white in color. Texture should be fine-grained } \\
\text { and firm. }\end{array}$ \\
\hline Beef & $\begin{array}{l}\text { Vacuum-packed beef will have a darker, bluish-red color until packaging is removed. } \\
\text { The red color of ground beef decreases as the amount of fat increases. } \\
\text { Increased fat content usually means a lower price; however, expect shrinkage to } \\
\text { occur during cooking. }\end{array}$ \\
\hline
\end{tabular}

Click here to learn about Purdue's Purchasing Meat. 


\section{Recipe Ideas}

Visit these links to research grilling recipes.

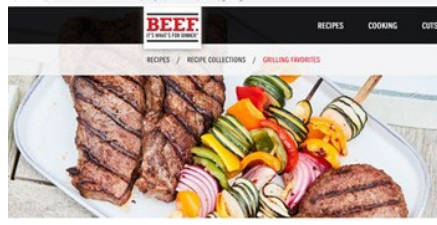

(x)

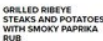

$y=-\infty$

$\stackrel{30}{-4} .810 .659$

$\begin{array}{lll}0 & 0 & 0 \\ - & 0 & 0\end{array}$

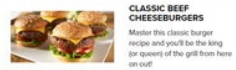

30 4.390

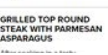

Click here to learn about Beef Grilling Recipes

\section{NATIONAL}

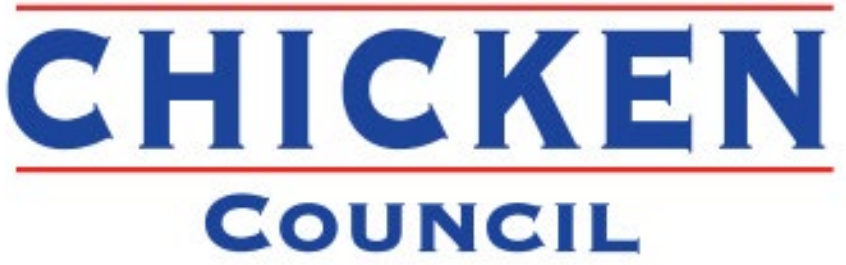

Click here to learn about Chicken Grilling Recipes

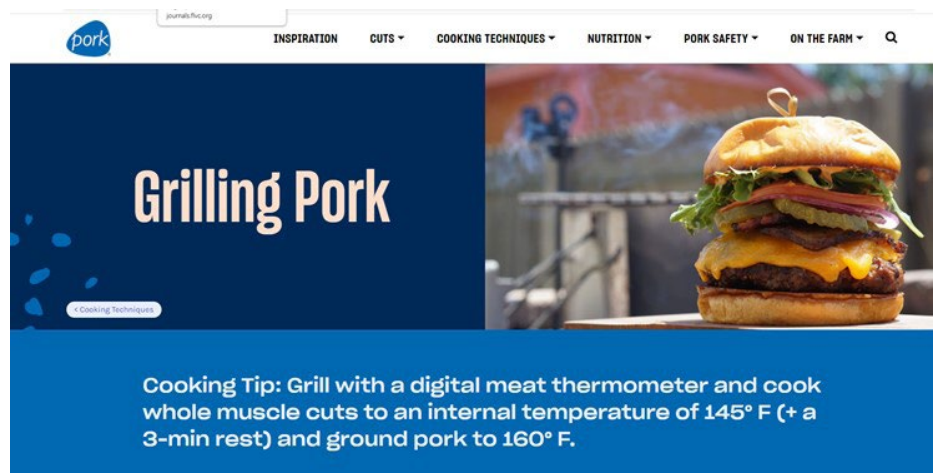

Click here to learn about Pork Grilling Recipes

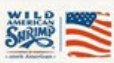

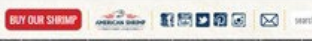

$\rightarrow$ RECIPSS
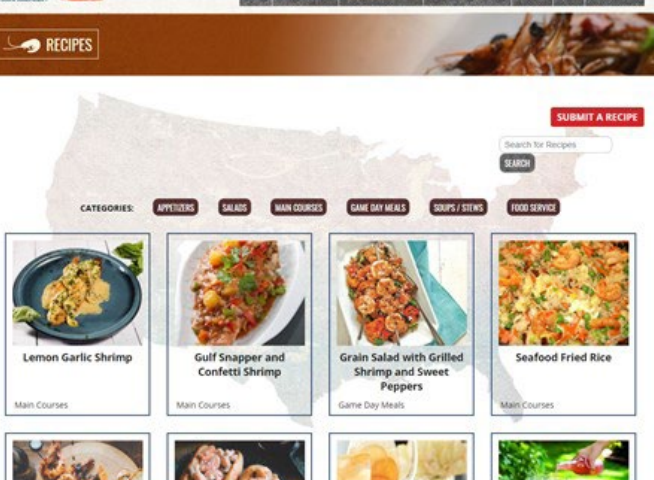

Click here to learn about Shrimp Grilling Recipes 


\section{Tabletop Display}

The Florida 4-H Tailgating Contest requires participants to create a tabletop display to show off their recipe and creativity. Participants may use a laptop/iPad/poster \& easel to complement their tabletop display to describe their recipe.

What should be included in my display?

- Poster

» Recipe

» Grill safety

»Pathogens

- Recipe cards (10) (optional)

- Fire-safe decorations (optional)

- Apron (optional)

- Other display items (as needed)
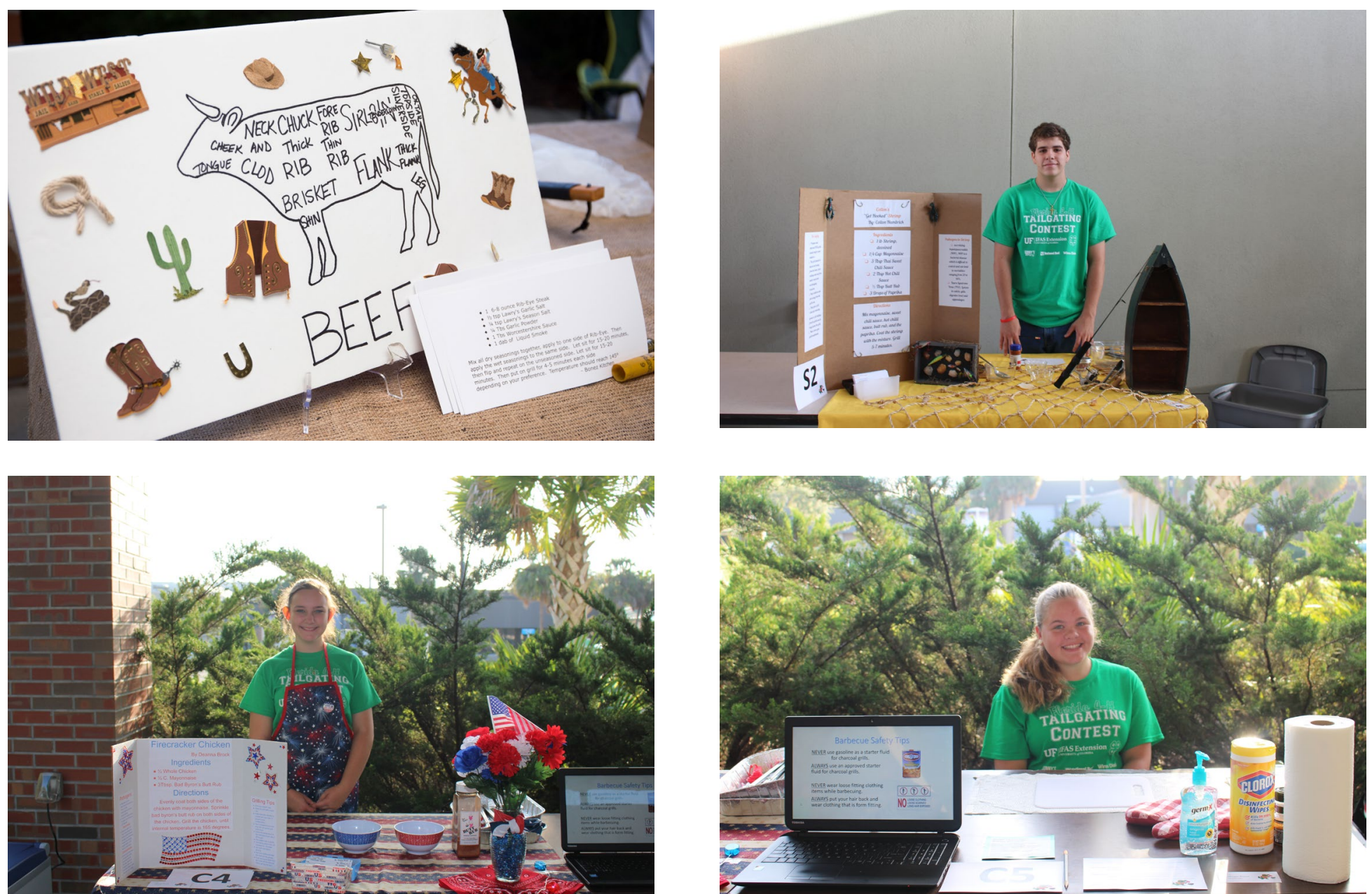

Tablecloths are no longer allowed at the Florida 4-H Tailgating Contest. 
Click here for more information on the Florida 4-H Tailgating Contest

Click here for more information about participating in the Virtual Tailgating Day Camp
ब̊.

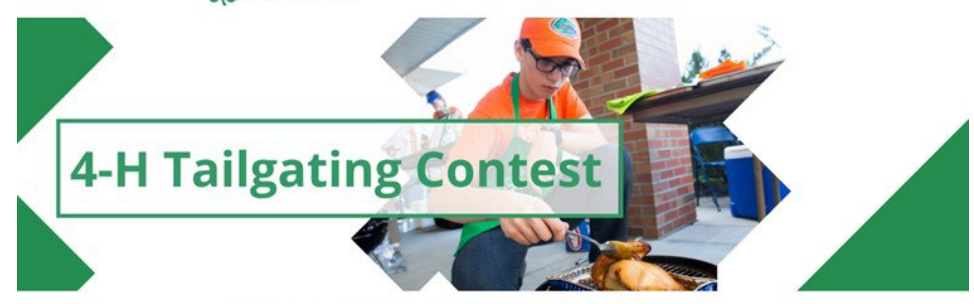

2021 REGIONAL \& STATE CHAMPIONSHIP 4.H TALGGATING CONTEST

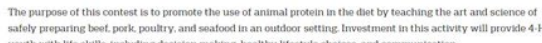

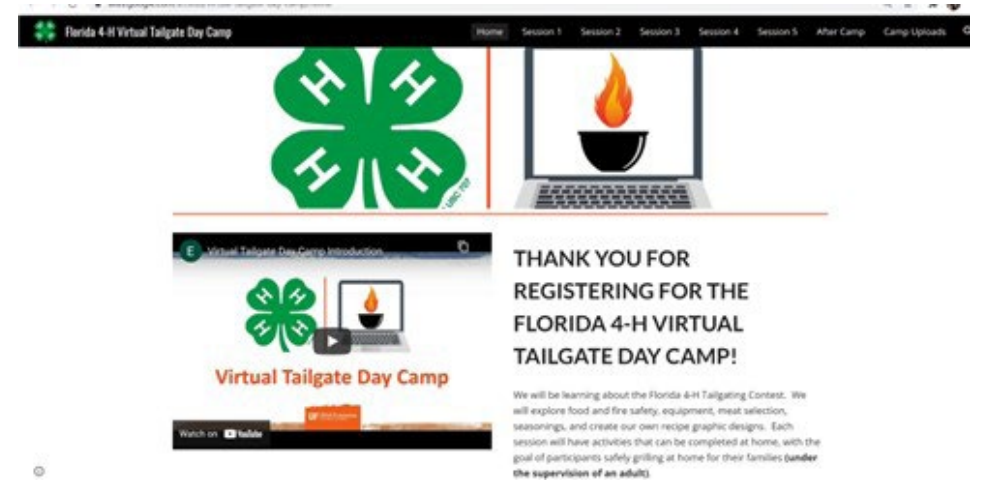

\section{Thank you to our sponsors of the Florida 4-H Tailgating Contest}




\section{Intended Audience and Purpose}

This document is intended for $4-\mathrm{H}$ members who want to participate in the Florida 4- $\mathrm{H}$ Tailgating

Contest. The purpose of this document is to provide all relevant resources for youth to be able to participate in the Florida 4-H Tailgating Contest.

\section{Authors}

Brian Estevez

Chad Carr

Deanna Brock

Sonja Crawford

Mark Mauldin

Shayla Reighter

Laura Bennett

Caroline Chappell

Aly Schortinghouse

Nick Simmons 

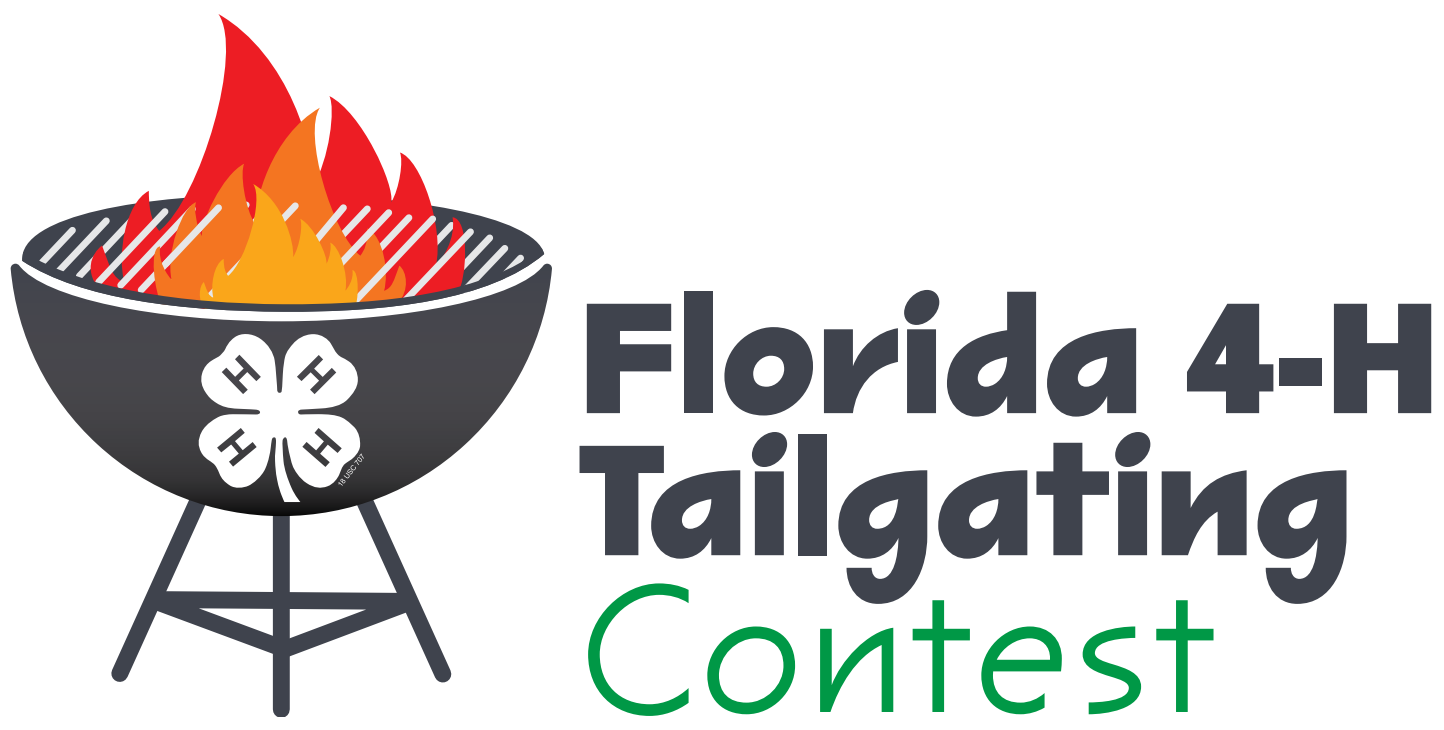

\section{UF $\mid$ IFAS Extension}

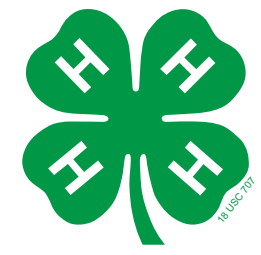

